\title{
THE PLACES OF (NON)REMEMBRANCE - THE USE OF DIGITAL TECHNOLOGIES IN CREATING THE PLACES OF COLLECTIVE MEMORY
}

\author{
DOI: 10.18485/arh_pt.2020.7.ch16
}

\author{
_ Milja Mladenović \\ PhD Student, Faculty of Architecture, University of Belgrade, Bulevar kralja \\ Aleksandra 73/II, 11000 Belgrade, Serbia, miljamladenovic@outlook.com
}

\section{ABSTRACT}

The topic of the paper is related to the processes of promoting the cultural heritage of Belgrade by creating a system of interactive places of remembrance. By identifying the relevant and the forgotten landmarks of Belgrade, the research aims to revive the stories of the places that played a role in the cultural development of the city but remain unmarked to this day. In the research, the landmarks are named "Mesta (Ne)Sećanja" - The places of (Non)Remembrance. The paper aims to define the means of creating site-specific virtual memorials that promote the identity of Belgrade, while simultaneously implementing the "Digital City" concept of urban development. The polygon of research is divided into two zones of Belgrade city centre, that are most visited by tourists. The focus of the work is connecting the 24 historically relevant and unmarked places in Belgrade in a single GIS-based network, which can be accessed by mobile phones or tablets in the specific locations. By connecting the georeferenced places with stories and augmented-reality (AR) models that provide interaction with users in real-time, it is possible to design virtual memorials that create the interference between the physical public space marked in 24 locations and virtual space at the specific web page or application. The paper relies on the results of an experimental project "Mesta (Ne)Sećanja" (The Places of (Non)Remembrance) conducted in 2017 that tested the implementation of the concept at the location of the "Kafana Albanija" historical landmark. The results include the numerical data of user interaction with the digital memorial as well as the guidelines for the physical sign of the memorial in the exact location, based on the tested design variables.

KEYWORDS _ "Mesta (Ne)Sećanja", site-specific, public art, augmented reality, digital memorials

\section{INTRODUCTION}

Contemporary development of various social, ecological, and technological factors influencing city development has affected the architectural approach of public space. By intertwining different possible scenarios of maintaining a contemporary public life in the old cities, the borders of material space are being questioned. The requirement for interaction in the cognitive process of getting to know a certain space has affected the architecture in terms of interlocking the cyberspace with the material space (Virilio, 2011). The contemporary city concepts require the use of new technology when interpreting elements of cultural heritage in public spaces. The new relation between technology and space is being constructed, and it serves as a medium of digitalized interaction in the form of digital projections, 3D Mapping, holograms, augmented reality installations, and different means of virtual or mixed reality activities. With such use, the technology becomes both the activator and the generator of the public life and also gives new meaning to the relation of time-space-information (Renaud, 2002). 


\section{NEW MEDIA AND CULTURAL HERITAGE}

The switch from analogue to digital technology in architecture and urban planning has enabled a new way of interpreting the cultural heritage, both trough productive and reproductive aspects (Malpas, 2007). Elements of technology can be involved in a digital reconstruction of existing spatial elements as reproductive, or create an entirely new architectural or artistic structure, even aesthetically identical to the original element of heritage - as productive. From the aspect of architecture and urban planning and the project "Places of (Non)Remembrance", the focus of the paper will be on the productive aspect of heritage interpretation, which creates a new aesthetical value (Mako, 2009) identical to the artefact, but in a digital medium. Since the concept of a virtual world knows no boundaries (Zancheti, 2002), because it happens in interaction with personal devices, the recognition of heritage value is being made possible if being designed as site-specific, by virtually interpreting an artefact in cyberspace but in its exact location - on site. For the given relation time-space-information, the time value is treated differently since the interaction through technology (devices) enables a faster flow of information.

The interaction through new media is enabled by a growth in the accessibility of public internet access points that are currently an important part of urban mobiliary, especially as it relates to the implementation of the "Digital City" concept. With accessible internet hotspots, it is easy to create web-based platforms for VR, AR, or other digital interaction. And with the development of smartphone technologies as well as other personal devices, it is now possible to scan QR codes with a device without the need for additional software or applications, which enhances the accessibility of heritage-related digital platforms.

\section{PLACES OF (NON)REMEMBRANCE}

\section{Case of Belgrade - Unmarked Landmarks}

The heritage of the Belgrade city centre is a rich field of various fragments of history. In many of the spots of the historic area, it is possible to recognise multiple historical layers of heritage that has no physical interpretation or landmark at present. Especially when it comes to the elements of cultural heritage related to everyday life, there has not yet been a consolidated method of categorizing the places of relevance that are related to many urban legends or historical events, which are significant for both the city and the region.

In the research conducted in 2017 there had been recognised over 20 possible places of collective memory that can be connected in tourist paths within a walking distance. Since the new urban concepts, such as Smart City, promote the pedestrian way of urban mobility, it is of a higher significance for urban development to find ways of promoting both the smart mobility and the smart heritage preservation methods. For the project "Mesta (Ne)Sećanja" the landmarks were connected in two networks - linear and polygonal, that tell the historical tale of Belgrade.

\section{Concept}

The project and the research were a part of Public Art and Public Space Course at the Faculty of Architecture, intending to create small urban interventions within Belgrade city centre. The first part of the project was related to recognising the possible spots for further research, and the second part was designing an architectural intervention that communicates with the users of public space. For the project, 24 unmarked landmarks created the touristic path (Figure 1). Since the attractiveness of a place in contemporary world is connected to a digital sphere, the marking of the landmarks was designed as a system of QR codes positioned at the site-specific spots. When scanned, the codes lead to a webpage with the story of the place in the Serbian and English languages, with audio-visual materials from various digital archives. Besides the touristic potential, the project also targets the citizens of Belgrade in attempt to familiarize them with the lesser-known elements of their city's 
heritage. By doing so, it is possible to raise awareness of the value of cultural heritage with the inhabitants.

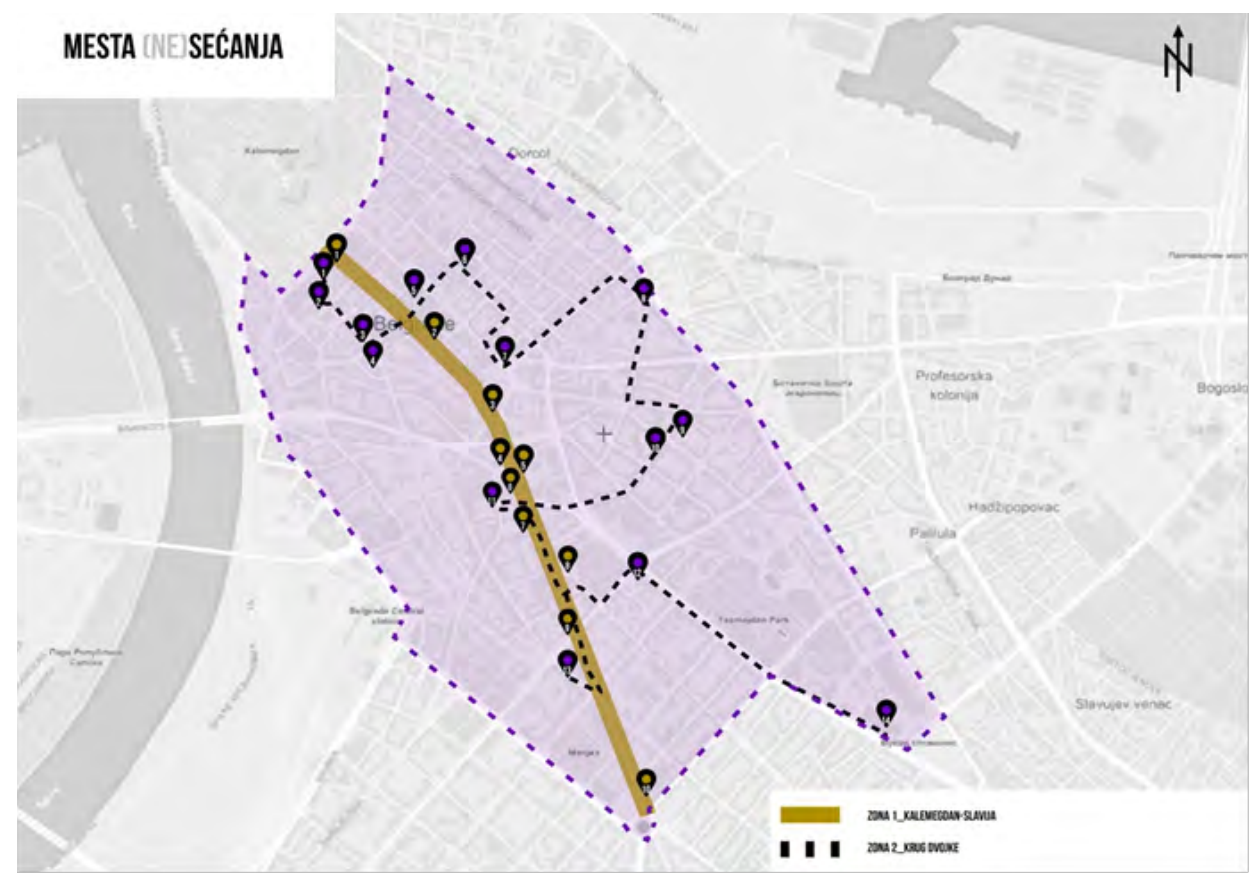

__ Figure 1: Map of "Mesta (Ne)Sećanja" Landmarks

The linear zone of landmarks traces the path from Kalemegdan to Slavia Square, following the Knez Mihailova Street, Terazije Square and Kralja Milana Street and consists of a network of 10 landmarks:

1. The place of the announcement of the beginning of WWI (Today the Faculty of Fine Arts)

2. The American Library (Today the Cervantes Institute)

3. The Kafana Albanija (Today the Palace Albania)

4. The hotel where Ivo Andrić wrote the novel Prokleta avlija

5. First cinema projection

6. The first location of The Victor Monument

7. The site of the Founding of the Kingdom of Serbs, Croats and Slovenes

8. The site of Obrenović Palace

9. The Jovan Bulj traffic officer Crossroad

10. The site of the Sundial in "Mitićeva rupa"

The polygonal zone consists of 14 landmarks related to everyday life, such as the site of the beginning of the Student Revolution in 1968, the first discotheque, the first brewery, the first private pizza-place, the first telephone, the first streetlight, etc. The landmarks 3 and 9 of the linear zone were chosen for the further development of the project.

\section{How it works?}

The design of the "memorial" consists of a mark with a printed QR code, located at the exact site of a historical event (Figure 2). When scanned by a user with a personal device, a webpage http://mestanesecanja.blogspot.com/ with the information about the site opens (Figure 3). At the webpage it is possible to interact with the data, and also find the nearby digital monuments within the zone, within the GIS map. 

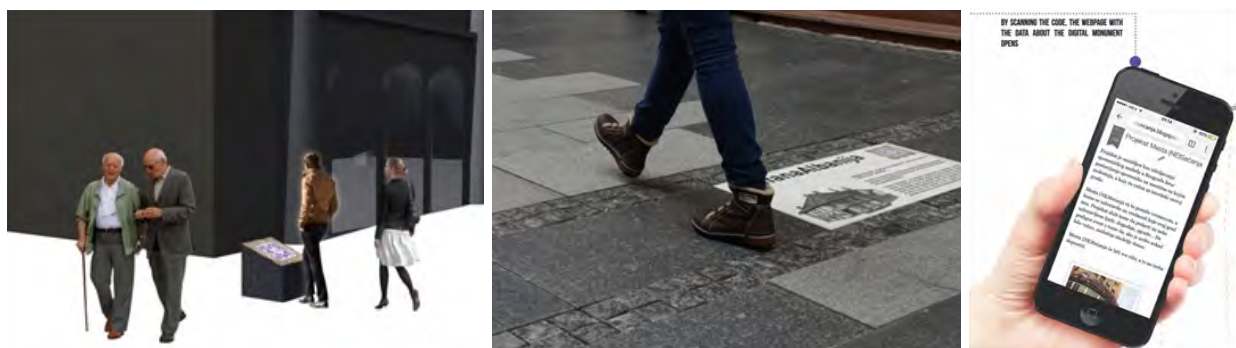

_ Figure 2 (left and in the middle): The design concept and Figure 3 (right): The webpage

\section{The results of the experiment}

The analysis and the numerical data (Table 1) provided by the experiment at "Kafana Albanija" and "Jovan Bulj Crossroad" points of "Mesta (Ne)Sećanja" in December 2017 are focused on recognising the digital sphere as the medium of communication between users and information in public space. It was conducted both in site-specific areas, as well as the virtual sphere of social networks. The gathering of the data had a duration of 24 hours, targeting the most frequent use of marked space. While the interaction with the "monuments" in public space had only several interactions, the viral results from social networks show the interest in topic, as well as the tendency to switch to more digital mediums. By making the user-information relation more accessible in the public space, it can be anticipated that the further research in the field can result in wider range of interaction that connects public space and virtual data in site-specific spatial points.

_ Table 1: Numerical data, December 2017

\begin{tabular}{|c|c|c|c|c|c|}
\hline & $\begin{array}{l}\text { QR Code } \\
\text { readings in } \\
\text { site }\end{array}$ & $\begin{array}{c}\text { Social Media } \\
\text { interactions - } \\
\text { Reach (Twitter) }\end{array}$ & $\begin{array}{l}\text { Social Media } \\
\text { interractions - } \\
\text { Link Clicks } \\
\text { (Twitter) }\end{array}$ & $\begin{array}{c}\text { Social Media } \\
\text { interractions - Link } \\
\text { Clicks (Shared } \\
\text { data) }\end{array}$ & $\begin{array}{c}\text { Blogpost } \\
\text { interaction }\end{array}$ \\
\hline Kafana Albanija & 14 & 2049 & 16 & 46 & 76 \\
\hline Jovan Bulj Crossroad & 7 & 1504 & 29 & 16 & 52 \\
\hline
\end{tabular}

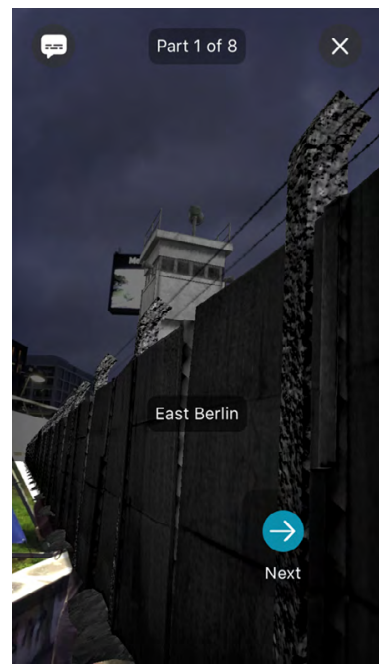

\section{Guidelines for further development of the project}

Due to the technology requirements which were higher in 2017 than they are now, there were issues with the scanning of the codes, since the devices didn't have a built-in code reader. From today's perspective, the scanning of QR codes is much simpler, and the interactions it provides are richer. Now it is possible to create an application with GIS based AR models, which can have a function of a digital memorial. Instead of a webpage with text and archive data, a user can have a more interactive experience with the model in virtual space. In a contemporary setting, this project can refer to the AR application used at the 30 Jahre Mauerfall event in Berlin in 2019 (Figure 4), as a guideline. 


\section{CONCLUSIONS}

By treating cultural heritage as a form of digital information, it is possible to enable a new method of promoting heritage throughout public space. The relation space-information transforms from a material space to digital, thus providing the ability to layer different heritage values within the digital medium. By using AR, VR, 3D mapping, and other digital means for user interaction, the promotion of heritage in the cities becomes more attractive to diversified social groups. By accepting the new media as a way of creating monuments, it is possible to implement the Smart City concept and to pursue a contemporary approach to cultural heritage protection. In cities such as Belgrade, where cultural heritage plays an important role within the inhabitants, it is important to create landmarks that don't interfere with the material space but enrich it from the point of the virtual sphere. Especially within the protected sites, it is important to recognise the value of cultural elements and reconstruct them in a way that doesn't include an invasive spatial intervention. The positive side of "digitalizing" such heritage is the possibility to adjust the information to the user, and to update it frequently, which is accomplished easier in the digital sphere all while preserving and promoting heritage sites.

\section{REFERENCES}

_- Đukić, A., Antonić, B., Stanković, R., \& Tatić, D. 2019. Digital Mini-museum as an Innovative and Affordable Presentation of Local Heritage for Tourists: Example from Serbia. Book of Proceedings of the 3rd International Conference on Tourism and Business 2019 Thailand: Mahidol University International College. 1-11 - Bolnov, O. 2012. Upotreba reči „prostor“ i „etimologija”. U Bojanić, P., Đokić, V. (ur.) Arhitektura kao gest, Beograd: Arhitektonski fakultet u Beogradu. 189-198

- Brajković, J. A. 2017. Novomedijska arhitektura - modaliteti upotrebe novih medija u arhitektonskoj prak-

si. Beograd: Arhitektonski fakultet.

- Castells, M. 2010. The Rise of the Network Society. Oxford: Blackwell Publishers.

- Dewdney, A., \& Ride, P. 2006. The New Media Handbook. London: Routledge.

- Eko, U. 2009 Funkcija i znak: semiotika arhitekture. U Bojanić, P., Đokić, V. (ur.) Teorija arhitekture i urban-

izma. Beograd: Arhitektonski fakultet u Beogradu. 155-173

- Foucault, M. 1986. Of Other Spaces. Diacritics No 16, 22-27.

- Ghani, I. A. 2010. Sustaining Cultural Heritage: Sence of Place in Virtual Heritage Environment. 4th International Conference on Built Environment in Developing Countries. Penang. 738-746

- Hampton, K. N., Livio, O., \& Sessions Goulet, L. 201. The Social Life of Wireless Urban Spaces: Internet Use, Social Networks, and the Public Realm. Journal of Communication, 701-722.

- Kastels, M. 2012. Nova istorijska veza između prostora i društva, U Bojanić, P., Đokić, V. (ur.) Arhitektura kao gest, Beograd: Arhitektonski fakultet u Beogradu. 363-376

- Mako, V. 2009. Estetika - Arhitektura, knjiga 1. Beograd: Orion Art

- Malpas, J. 2007. Cultural Heritage in the Age of New Media. U Y. Kalay, T. Kvan, \& J. Affleck, New Heritage: New Media and Cultural Heritage. New York: Routledge. 23-36

- Manovič, L. 2015. Jezik novih medija. Beograd: Clio.

- Nolberg - Šulc, K. 2009. Fenomen mesta. U Bojanić, P., Đokić, V. (ur.) Teorija arhitekture i urbanizma. Beograd: Arhitektonski fakultet u Beogradu. 260-273

_ Ože, M. 2005. Nemesta. Beograd: Biblioteka XX vek.

- Petruševski, I. 2016. Interaktivne instalacije u javnom gradskom prostoru: Istraživanje međudejstva čovek-svetlost-zvuk. Beograd: Arhitektonski fakultet.

- Rajt, G. 2009 Urbani prostori kao kulturni okviri. U Bojanić, P., Đokić, V. (ur.) Teorija arhitekture i urbanizma. Beograd: Arhitektonski fakultet u Beogradu. 329-335

- Ralević, M., Mrđenović, T., Božović, R., \& Muminović, E. 2017. The Routes of Digitalization: A Runaway City? Facta Universitatis, 15-28. 
_- Renaud, A. 2002, septembar. Memory and the Digital World. Museum International No 215 (Vol 15 No 3). Oxford: Blackwell Publishers. 8-18

- Stupar, A. 2008. Living in Technopolis: Between Reality and Imagination. Spatium, 21-26.

- Teodorou, M. 2009. Prostor kao iskustvo: Hore/Horos. U Bojanić, P., Đokić, V. (ur.) Teorija arhitekture $i$ urbanizma. Beograd: Arhitektonski fakultet u Beogradu. 174-190

- Virilio, P. (2011). Kritični prostor. Beograd: Gradac.

- Wellman, B. (2001). Physical Place and Cyberplace: The Rise of Personalized Networking. International Journal of Urban and Regional Research, 227-252

_ Zancheti, S. M. (2002, septembar). Values, Built Heritage and Cyberspace. Museum International No 215 (Vol 15 No 3). Blackwell Publishers. 19-28 